\title{
Cell therapy for refractory angina: time for more ACTion
}

\author{
Peter J Psaltis and Robert D Simari*
}

\begin{abstract}
Chronic ischemic heart disease is a major cause of patient morbidity and healthcare expenditure. The development of therapies aimed to enhance angiogenesis is targeted for patients with severe ischemic symptoms that persist despite optimized medical therapy and in whom coronary revascularization procedures are no longer feasible or helpful. Several different stem, progenitor and mature cell types have so far shown potential to improve myocardial perfusion and vascularity after transplantation in preclinical models of ischemia. However, human studies of cell-based transfer have heavily focused on preventing cardiac remodeling and dysfunction in the setting of myocardial infarction, while relatively few have addressed the use of cells to treat patients suffering from chronic debilitating angina. To this end, the recent ACT34-CMI trial represents a seminal milestone in the clinical evolution of cell therapy for chronic ischemic heart disease. In this phase II placebo-controlled study, myocardial injection of autologous peripheral bloodderived CD34+ progenitor cells was shown to confer considerable benefit for symptom frequency and exercise tolerance in patients with refractory, class III and IV angina. The present commentary reviews the key lessons from this unique trial and considers its contributions in moving the field of cell-based cardiovascular research forward.
\end{abstract}

Ischemic heart disease (IHD) confers significant morbidity and mortality despite advances in medical therapy and percutaneous and surgical revascularization. Based on unmet clinical need, the development of new treatment strategies, such as cell delivery, has progressively

*Correspondence: simari.robert@mayo.edu

Division of Cardiovascular Diseases, Mayo Clinic, 200 First St SW, Rochester, MN 55905, USA grown in momentum over the past decade. To date, many cell types have been applied experimentally for their potential reparative cardiac benefits. As challenges have become apparent for each cell candidate, preclinical investigators have set about tackling them with great vigor, pushing forward at a rapid rate with the optimization of newer-generation cell products and delivery techniques. Although the merits of translation to clinical practice have been debated on grounds of insufficient mechanistic data, uncertainty about cell biology and suboptimal engraftment and regenerative potential, this has not deterred evaluation of cell therapy in patients from continuing at a global level.

Initially conceived as a regenerative strategy to address the loss of cardiomyocytes after myocardial injury, most clinical studies have investigated the delivery of cells to affect ventricular remodeling after myocardial infarction (MI). Although different trials have shown conflicting outcomes, summarized data have concluded that cell therapy has a good safety record after MI, with overall modest benefits on surrogate endpoints, including ejection fraction and infarct size [1]. By comparison with MI, other cardiovascular patient groups with similar scope for benefit from cell delivery have not been investigated as aggressively.

Against this backdrop, the recently published, multicenter, phase II ACT34-CMI trial [2] represents a novel and worthwhile contribution to the body of human cell therapy experience. On the basis of preclinical observations and encouraging findings from an earlier phase I/ IIa study [3], Losordo and colleagues hypothesized that catheter-based injection of blood-derived $\mathrm{CD}_{4} 4^{+}$progenitor cells into regions of ischemic myocardium would result in improvement in angina frequency and exercise tolerance in patients with class III and IV chronic refractory angina. They randomized 167 subjects to receive either low-dose $\left(1 \times 10^{5}\right.$ cells $\left./ \mathrm{kg}\right)$ or high-dose $\left(5 \times 10^{5} / \mathrm{kg}\right)$ $\mathrm{CD}_{4} 4^{+}$cells after mobilization with granulocyte colonystimulating factor or placebo. These patients constituted an at-need cohort, with frequent symptoms of IHD despite maximal anti-anginal pharmacotherapy, and had exhausted therapeutic options for percutaneous or surgical revascularization. As such, they represented an 
ideal target for treatment with an experimental agent due to their favorable risk-benefit ratio. In addition, as highlighted by the investigators, the problem of refractory angina is of considerable magnitude to society, affecting up to 850,000 people per year in the United States, although population-based estimates may vary [4]. Enrollment of these patients into clinical trials can be challenging and previous studies of cell therapy for chronic IHD have comprised smaller sample sizes $[3,5,6]$.

The choice of $\mathrm{CD}_{3} 4^{+}$progenitor cells to reduce myocardial ischemic burden has a solid preclinical rationale and reflects an important advance from the status quo of human studies, which have mostly used the total cell content or mononuclear cell fraction of bone marrow (BM) aspirates [7]. Although easy to isolate, unselected BM cell preparations are heterogeneous and contain a very low percentage of immature progenitor or stem cells. In theory, this may limit their therapeutic capacity and better outcomes might be intuitively expected by implementing more enriched progenitor cell populations. Since their original description, our understanding of the biological nature of $\mathrm{CD} 4^{+}$cells has taken a circuitous course, from the initial notion that these were endothelial progenitor cells to increasing recognition of their hematopoietic lineage [8]. Irrespective, these cells are well known to have striking provasculogenic properties, mediated in large part through paracrine mechanisms. In animal models of myocardial ischemia, their transplantation has resulted in favorable effects on myocardial capillary density, perfusion, collagen deposition and contractile function that have been shown to exceed those obtained from unfractionated BM cells [9].

Importantly, the ACT34-CMI trial has confirmed that these mechanistic effects extend to improvement in clinical endpoints in patients with chronic IHD. By comparison with placebo, recipients of a low cell dose exhibited a strong reduction in weekly angina frequency and a doubling of exercise tolerance time at 6 and 12 months of follow-up. This was accompanied by trends favoring cell therapy in angina class, symptom questionnaire responses and use of sublingual nitroglycerines, along with nonsignificant decreases in mortality and major cardiovascular event rates. Interestingly, all positive outcomes were more modest and not statistically definitive in patients who received a high cell dose. Myocardial perfusion imaging with single-photon emission computed tomography also revealed an improvement in total severity score in the low-dose group compared with placebo, although differences were not found for other perfusion parameters. The authors rationalized that $\mathrm{CD} 4^{+}$cell delivery may have mediated symptomatic benefit by imparting microvascular changes that might not be detectable by conventional single-photon emission computed tomography imaging. Overall, the safety profile of cell treatment was also acceptable. Not surprisingly, administration of granulocyte colony-stimulating factor was found to exacerbate angina episodes and to induce mild cardiac biomarker release, while there were two cases of myocardial perforation caused by intramyocardial cell injection.

One of the acknowledged limitations of early cell therapy studies was that their nonrandomized design and use of surrogate endpoints may have resulted in overinterpretation of therapeutic results. In this regard, the ACT34-CMI trial is meritorious in primarily focusing on parameters that are of immediate clinical relevance, using measurements that are robust and rigorous. The persistence of symptomatic improvement at 12-month followup in the low-dose group is especially reassuring, as previous data have suggested that the incremental benefit from BM cell therapy for MI may only be transient. Although not powered to specifically compare outcomes between low-dose and high-dose cell therapy, the ACT34-CMI trial also highlights that the cell dose is a determinant of therapeutic response, but not necessarily in the intuitive sense that more cells equate to a larger effect. This is consistent with animal data showing that cells have an optimal ceiling dose, above which engraftment and functional biology may be compromised due to depletion of nutritional resources in the substrate myocardium [10].

In the setting of autologous BM cell therapy for MI, it is now understood that technical inconsistencies in cell preparation may have contributed to the discrepant outcomes between different studies. It is therefore highly encouraging for large-scale clinical application that the ACT34-CMI investigators were able to successfully coordinate and execute a multistep process for $\mathrm{CD}_{3} 4^{+}$ mobilization, collection, enrichment and lot testing locally, at each of 26 study sites. Furthermore, individual centers were also responsible for administering cells by percutaneous, catheter-based intramyocardial injection, under the guidance of $\mathrm{NOGA}^{\oplus} \mathrm{XP}$ electromechanical navigation (Biologics Delivery Systems Group, Cordis Corporation, Diamond Bar, CA, USA), which requires specialized training and a level of technical expertise beyond traditional injection of cells down the coronary arterial tree.

As cardiovascular regenerative medicine rides the wave of ongoing developments in cell and tissue engineering and the promise of impending results from current and future clinical trials, the ACT34-CMI trial provides a timely template for the study of patients with chronic IHD. With sound evidence for feasibility, safety and bioactivity, a phase III study of enriched, CD $34^{+}$proangiogenic cells now appears ready for commencement. Although skeptics may advocate deferral pending further preclinical evaluation, the rigorous execution of carefully designed human studies with meaningful endpoints 
should help focus and complement the questions asked by basic science and provide crucial momentum to keep this exciting field of research moving closer to clinical reality.

\section{Abbreviations}

$\mathrm{BM}$, bone marrow; $I H D$, ischemic heart disease; $\mathrm{MI}$, myocardial infarction.

\section{Competing interests}

The authors declare they have no competing interests.

Authors' contributions

PJP and RDS both contributed to the writing and approval of the final manuscript.

\section{Acknowledgements}

PJP is the recipient of an Overseas Biomedical Fellowship from the National Health and Medical Research Council of Australia and of the Marjorie Hooper

Overseas Fellowship from the Royal Australasian College of Physicians.

Published: 9 November 2011

\section{References}

1. Martin-Rendon E, Brunskill SJ, Hyde CJ, Stanworth SJ, Mathur A, Watt SM: Autologous bone marrow stem cells to treat acute myocardial infarction: a systematic review. Eur Heart J 2008, 29:1807-1818.

2. Losordo DW, Henry TD, Davidson C, Sup Lee J, Costa MA, Bass T, Mendelsohn F, Fortuin FD, Pepine CJ, Traverse JH, Amrani D, Ewenstein BM, Riedel N, Story K, Barker K, Povsic TJ, Harrington RA, Schatz RA: Intramyocardial, autologous CD34+ cell therapy for refractory angina. Circ Res 2011, 109:428-436.

3. Losordo DW, Schatz RA, White CJ, Udelson JE, Veereshwarayya V, Durgin M, Poh KK, Weinstein R, Kearney M, Chaudhry M, Burg A, Eaton L, Heyd L, Thorne T, Shturman L, Hoffmeister P, Story K, Zak V, Dowling D, Traverse JH, Olson RE, Flanagan J, Sodano D, Murayama T, Kawamoto A, Kusano KF, Wollins J, Welt F, Shah P, Soukas P, Asahara T, Henry TD: Intramyocardial transplantation of autologous $\mathrm{CD}_{3}{ }^{+}$stem cells for intractable angina: a phase I/lla doubleblind, randomized controlled trial. Circulation 2007, 115:3165-3172.
4. Kiernan TJ, Boilson BA, Sandhu GS, Lennon RJ, Roger VL, Barsness GW, Lerman A, Rihal CS, Simari RD: Nonrevascularizable coronary artery disease following coronary artery bypass graft surgery: a population-based study in Olmsted County, Minnesota. Coron Artery Dis 2009, 20:106-111.

5. Tse HF, Thambar S, Kwong YL, Rowlings P, Bellamy G, McCrohon J, Thomas P, Bastian B, Chan JK, Lo G, Ho CL, Chan WS, Kwong RY, Parker A, Hauser TH, Chan J, Fong DY, Lau CP: Prospective randomized trial of direct endomyocardial implantation of bone marrow cells for treatment of severe coronary artery diseases (PROTECT-CAD trial). Eur Heart J 2007, 28:2998-3005.

6. van Ramshorst J, Bax JJ, Beeres SL, Dibbets-Schneider P, Roes SD, Stokkel MP, de Roos A, Fibbe WE, Zwaginga JJ, Boersma E, Schalij MJ, Atsma DE: Intramyocardial bone marrow cell injection for chronic myocardial ischemia: a randomized controlled trial. JAMA 2009, 301:1997-2004.

7. Schachinger $V$, Erbs $S$, Elsasser A, Haberbosch W, Hambrecht R, Holschermann H, Yu J, Corti R, Mathey DG, Hamm CW, Suselbeck T, Assmus B, Tonn T, Dimmeler S, Zeiher AM: Intracoronary bone marrow-derived progenitor cells in acute myocardial infarction. N Engl J Med 2006, 355:1210-1221.

8. Psaltis PJ, Harbuzariu A, Delacroix S, Holroyd EW, Simari RD: Resident vascular progenitor cells - diverse origins, phenotype, and function. $J$ Cardiovasc Trans/ Res 2011, 4:161-176.

9. Kawamoto A, Iwasaki H, Kusano K, Murayama T, Oyamada A, Silver M, Hulbert C, Gavin M, Hanley A, Ma H, Kearney M, ZakV, Asahara T, Losordo DW: CD34-positive cells exhibit increased potency and safety for therapeutic neovascularization after myocardial infarction compared with total mononuclear cells. Circulation 2006, 114:2163-2169.

10. Dixon JA, Gorman RC, Stroud RE, Bouges S, Hirotsugu H, Gorman JH, 3rd, Martens TP, Itescu S, Schuster MD, Plappert T, St John-Sutton MG, Spinale FG: Mesenchymal cell transplantation and myocardial remodeling after myocardial infarction. Circulation 2009, 120(Suppl 11):S220-S229.

doi:10.1186/scrt84

Cite this article as: Psaltis PJ, Simari RD: Cell therapy for refractory angina: time for more ACTion. Stem Cell Research \& Therapy 2011, 2:43. 